Р. О. Христіанінова

\title{
БЕЗСПОЛУЧНИКОВІ СКЛАДНОСУРЯДНІ РЕЧЕННЯ В СУЧАСНІЙ УКРАЇНСЬКІЙ МОВІ
}

\begin{abstract}
Христіанінова Р. О. Безсполучникові складносурядні речення в сучасній українській мові.

У статті комплексно досліджено безсполучникові складносурядні речення, закцентовано увагу на специфіці їхньої формально-граматичної та семантикосинтаксичної організації. Визначено характерні ознаки, що уможливлюють зарахування тих чи тих безсполучникових конструкцій до складносурядних, констатовано, що найпосутнішою 3 цих ознак постає граматична рівноправність предикативних частин та неспрямований синтаксичний зв'язок між ними.

Ключові слова: безсполучникове складносурядне речення, граматична рівноправність предикативних частин, неспрямований синтаксичний зв'язок, сурядний зв'язок.
\end{abstract}

Христианинова Р. А. Бессоюзные сложносочиненные предложения в современном украинском языке.

В статье осуществлено комплексное исследование бессоюзных сложносочиненных предложений, акцентируется внимание на специфике их формально-грамматической и семантико-синтаксической организации. Определены характерные признаки, которые дают возможность отнести те или иные бессоюзные конструкции к сложносочиненным, констатируется, что наиболее существенным из этих признаков является грамматическое равноправие предикативных частей и ненаправленная синтаксическая связь между ними.

Ключевые слова: бессоюзное сложносочинённое предложение, грамматическое равноправие предикативных частей, ненаправленная синтаксическая связь, сочинительная связь.

Khrystianinova R. O. Asyndetic compound sentences in modern Ukrainian language.

Asyndetic compound sentences are comprehensively investigated in the article, it is emphasized the specifics of their formal-grammatical and semantic-syntactic organization. The () Р. О. Христіанінова, 2013. 
characteristic features that make the admission of certain asyndetic structures to compound sentences are determined; it was stated that the most important of these signs is a grammatical equality of predicate parts as well as non-directional syntactic connection between them.

Key words: asyndetic compound sentences, grammatical equality of predicate parts syntactic non-directional connection, coordinated connection.

Постановка наукової проблеми та іiі значення. До середини $\mathrm{XX} \mathrm{ст.} \mathrm{складносурядними} \mathrm{традиційно} \mathrm{вважали} \mathrm{як} \mathrm{сполучникові,} \mathrm{так} \mathrm{i}$ безсполучникові речення, предикативні частини котрих рівноправні, граматично незалежні одна від одної. У 50-х роках минулого сторіччя М. С. Поспєлов запропонував принципово нове розуміння безсполучникових складних конструкцій: їх було визнано особливим структурно-семантичним класом складних речень і протиставлено складносурядним та складнопідрядним [6]. Під впливом наукових розвідок цього вченого безсполучникові речення як окремий тип розглядають багато українських синтаксистів другої половини XX початку XXI ст., у зв'язку 3 чим до складносурядних речень зараховують тільки сполучникові конструкції [4; 5; 7; 9; 10 та ін.]. Проте окремі мовознавці вбачають ознаки складносурядних речень і в частині складних безсполучникових конструкцій незамкненої структури. Зокрема російська дослідниця В.А. Бєлошапкова дає визначення складносурядних речень тільки на основі сурядного зв'язку і розглядає серед складносурядних речень безсполучникові конструкції відкритої структури [2, с. 656; 8, с. 520].

$\mathrm{B}$ україністиці останні десятиріччя XX ст. та початок XXI ст. ознаменовані розробленням засадничих принципів якісно нового підходу до аналізу граматичних одиниць - функційно-категорійного. Фундатором його є відомий український мовознавець I. Р. Вихованець, який і запропонував відмінну від традиційної класифікацію складних речень, побудовану на основі типів синтаксичного зв'язку між предикативними частинами. Відповідно до основних типів цього зв'язку він виокремив чотири класи базових складних речень: складносурядні, складнопідрядні, складні речення зі взаємозалежними частинами та безсполучникові складні речення з недиференційованим синтаксичним зв’ язком [1]. Підкреслимо, І. Р. Вихованець уважає, що «визначальні для складних речень сурядний i підрядний зв'язки поширюються на сполучниковий i безсполучниковий різновиди цих конструкцій» $[1$, с. 304]. На його думку, «належність деякої частини безсполучникових конструкцій до складносурядних i складнопідрядних речень визначається типом синтаксичного зв'язку - сурядним і підрядним, які виявляють тотожні синтаксичні властивості як у сполучникових, так i 
безсполучникових складних реченнях» [1, с. 348]. Згідно 3 функційнокатегорійним підходом до складносурядних речень належать i сполучникові, i безсполучникові утворення, предикативні частини яких поєднані сурядним зв'язком. Запропоноване потрактування лінгвістичної сутності складносурядних речень, на нашу думку, найпереконливіше та найумотивованіше, адже вибудувано його в одній логічній площині. Отже, головною диференційною рисою складносурядних речень $\epsilon$ сурядний зв'язок між предикативними частинами, що постають як граматично незалежні один від одного структурні компоненти складного речення і можуть бути поєднані за допомогою сполучників і без них.

Мета цієї розвідки - обгрунтувати можливість зарахування до складносурядних речень окремих типів безсполучникових конструкцій, проаналізувати формально-граматичну й семантикосинтаксичну структуру безсполучникових складносурядних речень, виокремити їхні семантико-синтаксичні типи.

Виклад основного матеріалу й обгрунтування результатів дослідження. Визначальною диференційною ознакою, що розмежовує основні типи синтаксичних зв'язків, править напрямок синтаксичної залежності між компонентами, поєднаними між собою синтаксичним зв’ язком. Сурядний зв'язок поєднує рівноправні, граматично незалежні один від одного компоненти, а отже, є неспрямованим, форма цього зв'язку - незалежна координація. Отже, граматична рівноправність предикативних частин, відсутність формально-граматичної залежності між ними постає основною ознакою складносурядних речень. Такі частини зазвичай поєднані сполучниками сурядності, що постають виразниками розгляданого зв'язку, однак можливе й безсполучникове поєднання граматично рівноправних частин, що дає підстави зарахувати до складносурядних речень і частину безсполучникових конструкцій. Характеризуючи безсполучникові складносурядні речення, I. Р. Вихованець наголошує, що в системі типів складносурядного речення безсполучникові утворення посідають незначне місце. Вони не мають такої розгалуженості семантико-синтаксичних відношень, яка властива сполучниковим складносурядним конструкціям, і функціюють у сфері однієї з груп складносурядних речень відкритої структури єднальних складносурядних речень зі значенням переліку. Потенційна необмеженість сурядного ряду й однотипність предикативних частин якраз і становлять специфіку безсполучникових складносурядних речень [1, с. 304-305]. У таких реченнях можливі два різновиди семантикосинтаксичних відношень - одночасності дій, процесів або станів та їхньої часової послідовності. 
Відтворювані в структурах зі значенням одночасності дії і факти об'єднані одним часовим відрізком. Перелічувані дії i явища перебувають у плані минулого: Калюжі миттєво пересохли, запах мокрої землі та хробаків здуло в гори (5, с. 14); Сонце палило, нагріте різнотрав'я пахтіло медовим духом, васильки та чебрець наче пригорілі були, поникло стояла шавлія з темно-синіми квітками та залізняк $з$ рожевим цьвітом... (2, т. V, с. 479); теперішнього: Нас літаки несуть над хмарами, Везуть на море кораблі (8, с. 439); Лиже полум'я жовте черево, Важкувато сопе димар, Галасує від болю дерево, Піднімаючись димом до хмар (10, с. 5) або майбутнього: Майне перехожии; прогуркоче трамвай; з диким вереском промчить кудись колона криваво-червоних пожежних машин (2, т. IV, с. 17); Пройдуть зливи, замовкнуть грози, Задрімають вітри на ланах... (10, с. 42). Предикативні частини, об'єднані відношеннями одночасності, можуть мати спільний компонент - найчастіше детермінант або навіть підрядну частину: I як завжди, але й не так Співають птиці, квітне мак, Хмарки пливуть, ліси синіють, Попід гаями ріки мріють (8, с. 450); Скоро зима забіліє снігами, вдарять морози... (8, с. 75); Коли вона прокинулась, на столі вже горіла свічка, в кімнаті нікого не було, у чорні смолисті вікна дріботів дощ... (1, с. 178); Коли Яворницький розповідав про це, очі його загорялись гнівом, суворими ставали слова... (4, с. 384). Спільний компонент зазвичай має чітко закріплене місце - стоїть у препозиції. Він виконує важливе семантичне навантаження: вказує на те, коли, де чи як відбувається все перелічуване в наступних предикативних компонентах. Препозицію спільного члена С. І. Дорошенко вважає конститутивною прикметою розглядуваного різновиду безсполучникових речень [3, с. 81]. Як значеннєво однорідні, компоненти одночасового плану зазвичай не мають чіткої закріпленості щодо порядку їхнього розташування, що дає змогу вважати безсполучникові складносурядні речення одночасності граматичними одиницями з гнучкою структурою.

За I. Р. Вихованцем, безсполучникові складносурядні речення, які вказують на відношення одночасності дій, процесів або станів, виявляють найвищий ступінь однотипності предикативних частин [1, с. 305]. Присудки в усіх предикативних частинах таких речень уживають зазвичай у тих самих часових формах: Золотіє вечірня тополя, Дивним світлом горять небеса (8, с. 438); Павук снує невтомно сіті, Бджола нектар з квіток збирає (8, с. 448); Ліси у ряст убралися барвисто, Дощуами квітень рясно відшумів (8, с. 59). Для відтворення подій, що стосуються теперішнього часу, зрідка можливе поєднання предикативних частин із формами теперішнього й минулого часу, але 
наголосимо, що предикативні частини з формою минулого часу завжди стоять у постпозиції, вони фіксують збережений дотепер результат завершених дій: Відлітають птахи, облітають сади, Спорожсніли поля $i$ городи (8, с. 45); Осінні дощі безкінечні і сірі, Птахи відлетіли, сховалися звірі (8, с. 67). Перенесення цих складників у препозицію змінює часове співвідношення передаваних подій - предикативні частини 3 дієсловами минулого часу постають як такі, що відтворюють події, які відбулися раніше, пор.: Спорожніли поля $і$ городи, відлітають птахи, облітають сади; Птахи відлетіли, сховалися звірі, осінні дощі безкінечні $i$ сірі. Однотипність предикативних частин часто спричиняє їхній паралелізм: Падав і не падав периий сніг, курилась і не курилась земля, підбиваючись під розкошлану димчасту куделю осіннього вечора (11, с. 60); Довго спали вітри у ярах на припоні, Довго тиша гнітюча полями повзла... (10, с. 38); Ще не лякає слово «строниій», Ще можна ніжитись на сонці, Ще чиста в Прип'яті вода, Іщуе чорнобильська біда I всюдисуща небезпека I нереальна, і далека... (8, с. 443). Розглядані безсполучникові складносурядні речення досить поширені в сучасній українській літературній мові. У художніх творах, особливо поетичних, вони часто функціюють поряд із такими самими сполучниковими, пор.: I nicня лунала, і чарка кружляла, I душу душа у любові купала (8, с. 161); I птиці щебечеть, і шепче колосся, I ніжний вітрець розвіває волосся (8, с. 226); Сніги у доші перейдуть, I знову усе стрепенеться, I жвваві струмки потечуть, I жайвір у небі зметнеться (8, с. 443); Поволі слід за ними заростає, I дощ свинцеевий землю засіває, I дно ріки встеляють блискавки, I, розметавии крила, ластівки Ширяють на чорнобильських вітрах, I чорні хмари навівають страх (8, с. 68-69). Нерідко однотипні сурядні частини поєднані в одному ряду і сполучниками, i без них: Цвіркун сюрчить, i сад иумить, Снуються тіні волохаті (8, с. 431); Цвіте барвінок, ряст цзвіте, I терен зацвітає (8, с. 455); Іржуть коні, дзвенить далечінь, $і$ плавом пливуть назустріч втомлені капітулюючі війська...(1, с. 415). Отже, безсполучникові і сполучникові складносурядні речення зі значенням одночасності $\epsilon$ формально-синтаксичними варіантами єднальних складносурядних речень з таким самим значенням.

Однотипними постають і предикативні частини: а) 3 формами наказового способу: Хай брехня твоє слово дугою не вигне, Хай не вірить твій розум в убогі слова (10, с. 35); б) співвідносні 3 номінативними простими реченнями: Вечір, поле, дорога в пшениці... (8, с. 95); Бур'ян, трава, дрімота (8, с. 291), що також уможливлює зарахування подібних безсполучникових конструкцій до єднальних складносурядних речень, пор.: Хай брехня твоє слово дугою не вигне $i$ (C) Р. О. Христіанінова, 2013. 
хай не вірить твій розум в убогі слова; Садок, $i$ пасіка, $і$ дід... $(8$, c. 207). Так само вважаємо за можливе розглядати як складносурядні єднальні речення безсполучникові утворення на взірець: Так $\epsilon$, так було завжди, так, мабуть, довіку буде, пор.: Так $\epsilon$, i так було завжди, I так, мабуть, довіку буде (8, с. 80).

У безсполучникових складносурядних реченнях зі значенням часової послідовності предикативні частини відтворюють перелік дій, фактів, явищ, котрі змінюють одні одних у часовій послідовності, що спричиняє закріпленість порядку предикативних частин і відповідно потрактування структури таких речень як негнучкої. За типову ознаку безсполучникових складносурядних речень часової послідовності зазвичай правлять різні форми присудків, лексичні показники часової послідовності та загальний зміст усієї складної конструкції: Достигло жито, споловіло жито, Вогнем червоним палахкочуть маки (8, с. 441); До війни, невдовзі після закінчення металургійного інституту, теперішній секретар керував заводською партійною організацією, потім висунули в міськком, далі в обком, під час війни став на одному 3 фронтів генералом (3, с. 493); Чорний згорток шкіри тьмяно блиснув у нього в руках, потім він витяг кілька пар червоноармійської білизни, два відрізи на шинелю, три пари нових галіфе, білу байку на онучі (12, с. 216); У ті ночі своєї самотності та неприкаяності Таня, блукаючи по слідах свого кохання, непомітно для себе заходила на вулицю Вільної академії... звідти щзось вело ї̈ на студентський «острів Кохання» над журавлівською кручею... (2, т. IV, с. 8); Минула осінь, одвіяла-відхурделила зима, настала бентежна пора рясту, пора зацввітань і одцвітань (11, с. 13).

Детальний аналіз формально-граматичної і семантико-синтаксичної структури безсполучникових складних конструкцій дає змогу, крім проаналізованих, зарахувати до складносурядних речень ще кілька їхніх груп.

Зокрема, є всі підстави віднести сюди безсполучникові утворення, предикативні частини яких пов'язані одним предметом думки: Костюм теліпався, наче на вішалиі, схудла шия сірником стирчала з великого коміра, Василь Гнатович затяг мічніше краватку і рішуче, посуплений... вийшов із спальні (7, с. 31); Життя було, воно брало своє... (3, с. 423). C. І. Дорошенко назвав їх «безсполучниковими складними структурами iз значенням сумісності дій» та визначив такі їхні специфічні риси: 1) вони не формують однорідного ряду перелічуваності; 2) у вираженні присудків предикативних інгредієнтів не завжди дотримана одночасність, хоч і немає послідовності в називанні дій [3, с. 85]. 
Здебільшого в цих реченнях попередня предикативна частина має загальніший зміст, вводить тему висловлення, а наступна частина іiі конкретизує. У таких конструкціях найчастіше в одній предикативній частині маємо іменник, а в іншій його замінює займенникове слово: Поруч, без вітру, просто від давнини чи дум зітхнув посивілий журавель,до одного кіния його навіки була ув'язана колода, на другому у свіжій бадді вода перехоплювала теплу зоряну обніж $(11$, с. 81), інколи друга частина неповна, у ній пропущене слово, яке називає спільний предмет думки: Дочекалася мати сина, Повернувся 3 війська... (8, с. 437) - Дочекалася мати сина, він повернувся з війська; Прозора скляна веранда, залита сірим грозовим світлом, вікна в підтьоках дощу... (5, с. 12) - Прозора скляна веранда, залита сірим грозовим світлом, ї̈ вікна в підтьоках дощу. Паралелізм предикативних частин для цих речень є хоч і можливим, але нетиповим явищем: $O$ дванадиятій в хаті тихо, О дванадиятій в хаті ясно, О дванадиятій ночі в хаті (8, с. 439); Ніч підходила з гуркотіннями, Ніч несла божевілля й жах, Плазувала потворними тінями У нервово пружних кущах (10, с. 76); Ми - цзвіт нащиї, ми - цзвіль нації (5, с. 14). Безсполучникові конструкції, предикативні частини яких пов'язані одним предметом думки, не завжди допускають уставлення сполучників сурядності, але граматична рівноправність їхніх предикативних частин безперечна, що й умотивовує можливість потрактування їх як складносурядних речень. Ці речення також виражають єднальні семантико-синтаксичні відношення між предикативними частинами.

Ще одну групу єднальних складносурядних безсполучникових речень, на нашу думку, утворюють конструкції з обмежувальним значенням, у другій предикативній частині яких наявні частки тільки, лише (лиш): До самого села не трапилося жодної живої душі, тільки де-не-де кам'яні хрести знов біліли над иляхом... (1, с. 28); Вранці ...nомітно безлюдніс Зачіплянка, тільки дітлашня, заїдена шовковицею, галасає на вулиці та біля саги (3, с. 429); Він не знав ні болю, ані ран, Лиш ганьба на все життя зосталась (8, с. 442); Дерева в заметах по крони, Безмовна лежить далина, Лише галасливі ворони Над лісом кричать дотемна (8, с. 250). Подібні утворення можна легко трансформувати в складносурядні сполучникові речення, пор.: До самого села не трапилося жодної живої душі, і тільки де-не-де кам'яні хрести знов біліли над иляхом; Вранці помітно безлюдніє Зачіплянка, і тільки дітлашня, заїдена шовковицею, галасає на вулиці та біля саги; Він не знав ні болю, ані ран, і лиш ганьба на все життя зосталась; Дерева в заметах по крони, Безмовна лежить далина, $i$ () Р. О. Христіанінова, 2013. 
лише галасливі ворони Над лісом кричать дотемна. І. І. Слинько, Н. В. Гуйванюк, М.Ф. Кобилянська $i$ тільки, $i$ лише вважають сполучниковими поєднаннями: Уже й збігла вода, $і$ тільки де-не-де в маленьких калюжах спалахує рання зоря (В. Земляк); Веселиться молодь, і лише ордени на грудях у юнаків нагадують недавню війну (Ю. Яновський) [7, с. 609]. Таке потрактування видається не зовсім коректним, про що свідчать, по-перше, конструкції без сполучника $i$ на зразок наведених вище, $\mathrm{i}$, по-друге, можливість перенесення часток тільки, лише в інтерпозицію: Але це відійшло, розтануло разом 3 ладанними димами, зостався для студента тільки оцей довершений архітектурний витвір, очя симфонія пластики (3, с. 413) - Але ще відійшло, розтануло разом з ладанними димами, $i$ зостався для студента тільки оцей довершений архітектурний витвір, оия симфонія пластики.

Убачаємо за можливе зарахувати до складносурядних речень також безсполучникові конструкції 3 чітко вираженим протиставним значенням між їхніми предикативними частинами, формованим запереченням у першій частині і ствердженням - у другій, уживанням у предикативних частинах лексичних або контекстуальних антонімів: $\mathrm{Hi}$, то не сум промінить риса кожна, то творчість б' $\epsilon$ з натхненних наших віч (10, с. 67); Не хвали сам себе, хай народ похвалить тебе (Н. тв.); Позаду - село, попереду - ліс (6, т. 2, с. 397); Він - паяи, комедіант, на найнижчому щаблі суспільства, вона - володарка світу, напівбогиня. Він потвора, вона - сліпуча красуня (6, т. 1, с. 40). За спостереженнями C. I. Дорошенка, такі утворення часто позначені «симетричним розташуванням слів в обох складових частинах» [3, с. 94].

Як складносурядні речення, на нашу думку, варто розглядати й безсполучникові конструкції 3 другою предикативною частиною приєднувального типу: Цього ще не було, можливості чогось такого Таня $і$ в думках не припускала... (2, т. IV, с. 15); Об’єктам якісної ознаки відведено третє рангове місие, оскільки вони значеннєво диференційовані меншою мірою, ніж об'єкти стану, до того ж більшість з них у предикатів якості мають факультативний вияв (9, с. 15), пор.: Цього ще не було, та й можливості чогось такого Таня $і$ в думках не припускала; Об'єктам якісної ознаки відведено трете рангове місие, оскільки вони значеннєво диференційовані меншою мірою, ніж об 'єкти стану, та й до того ж більшість з них у предикатів якості мають факультативний вияв. Деякі 3 цих конструкцій не допускають підставлення сурядного сполучника, але друга частина має всі ознаки приєднувальної - вона подає додаткову 
інформацію, додаткові зауваження до висловленого в першій частині, оцінку сказаного в ній, наслідок, що випливає зі змісту першої частини: Це завтра вже стало сьогодні, ось яка історія (2, т. IV, с. 11); Інші [ягнята] бігають, вибрикують, а иьього щзоразу треба підносити до матері; само не встигає за сакманом... (2, т. V, с. 8); У сукупність морфологічних варіантів об'єктного компонента входить як обов'язкова форма орудний відмінок, щуо сполучається з обмеженим колом дісслів керівництва, володіння, ставлення до об'єкта, моторними дієсловами; також він реалізує факультативну валентність деяких прикметникових предикатів... (9, с. 16).

Багатовимірний аналіз безсполучникових конструкцій дає підстави говорити про їхню належність до різних формальнограматичних типів складних речень. Частина 3 них репрезентує складносурядні речення. Предикативні частини безсполучникових складносурядних речень граматично незалежні, поєднані між собою сурядним зв'язком, між ними виникають єднальні, протиставні відношення, а також відношення «основна - додаткова інформація». На нашу думку, наведені в статті положення перспективні для подальшого вивчення безсполучникових складних конструкцій.

\section{Література}

1. Вихованець I. Р. Граматика української мови. Синтаксис : підруч. [для студ. філол. фак. вуз.] / І. Р. Вихованець. - К. : Либідь, 1993. - 368 с.

2. Грамматика современного русского литературного языка : синтаксис / глав. ред. Н. Ю. Шведова. - М. : Наука, 1970. - 767 с.

3. Дорошенко С. І. Наукові простори : [вибр. праці] / С. І. Дорошенко. - Харків : «Новое слово», 2009. - 488 с.

4. Загнітко А. П. Теоретична граматика української мови. Синтаксис : [монографія] / А. П. Загнітко. - Донецьк : ДонНУ, 2001. - 662 с.

5. Кулик Б. М. Курс сучасної української літературної мови. Синтаксис / Б. М. Кулик. - [2-е вид., перероб. і доп.]. - К. : Рад. школа, 1965. - 282 с.

6. Поспелов Н. С. О грамматической природе и принципах классификации бессоюзных сложных предложений / Н. С. Поспелов // Вопросы синтаксиса современного русского языка. - М. : Изд-во АН СССР, 1950. - С. 11-19.

7. Слинько I. І. Синтаксис сучасної української мови : Проблемні питання : [навч. посіб.] / І. І. Слинько, Н. В. Гуйванюк, М. Ф. Кобилянська. - К. : Вища школа, 1994. $-670 \mathrm{c}$.

8. Современный русский язык : учеб. [для филол. спец. ун-тов] / [В. А. Белошапкова, Е. А. Брызгунова, Е. А. Земская и др.] ; под ред. В. А. Белошапковой. - [2-е изд., испр. и доп.]. - М. : Высш. школа, 1989. - 800 с.

9. Сучасна українська літературна мова. Синтаксис / [за заг. ред. І. К. Білодіда]. К. : Наукова думка, 1972. -516 с.

10. Шульжук К.Ф. Синтаксис української мови : [підруч.] / К. Ф. Шульжук. - К. : Видавничий центр «Академія», 2004. - 408 с. 


\section{Джерела ілюстративного матеріалу}

1. Гончар О. Т. Прапороносці : [трилогія] / О. Т. Гончар. - К. : Дніпро, 1981. -471 с.

2. Гончар О. Т. Твори : у 7-и т. / О. Т. Гончар. - К. : Дніпро, 1987. - Т. 4. - 1987. 589 c. ; T. 5. $-1988 .-487$ c.

3. Гончар О. Т. Циклон. Тронка. Собор : [романи] / О. Т. Гончар. - К. : Рад. школа, 1990. $-592 \mathrm{c}$.

3. Гончар О. Т. Спогад про океан : [новели] / О. Т. Гончар. - К. : Веселка, 1995. - 398 с.

4. Дереш Любко. Культ : [роман] / Любко Дереш ; худож.-оформлювач І. В. Осіпов. - Харків : Фоліо, 2009. - 219 с.

5. Дімаров А. А. Вибрані твори : у 2-х т. / А. А. Дімаров. - К. : Дніпро, 1982. T. $1 .-535$ c. ; T. 2. -616 c.

6. Дімаров А. Містечкові історії : Листи з небуття / А. Дімаров. - К. : Дніпро, 1987. $-559 \mathrm{c}$.

7. Луків М. В. Балада про брата : [поезії] / М. В. Луків. - К. : КП «Редакція журналу «Дніпро», 2005. - 494 с.

8. Межов О. Г. Система мінімальних семантико-синтаксичних одиниць сучасної української літературної мови : автореф. дис. ... д-ра філол. наук : спец. 10.02.01 «Українська мова» / О. Г. Межов. - К., 2013. - 36 с.

9. Симоненко Василь. Вибране / В. Симоненко. - К. : Школа, 2002. -253 с.

10. Стельмах М. П. Чотири броди : [роман] / М. П. Стельмах. - К. : Дніпро, 1989. - 608 с.

11. Тютюнник Г. М. Вир : [роман] / Г. М. Тютюнник. - К. : Рад. школа, 1990. -512 с.

Стаття надійшла до редакції 24.10.2013 р. 